\title{
Effect of Timing of Nitrogen Split Application on Productivity, Nitrogen Use Efficiency and Economic Benefits of Food Barley (Hordium vulgare L.) in Central Highlands of Ethiopia
}

\author{
Sakatu Hunduma and Legesse Admassu \\ Ethiopian Institute of Agricultural Research, P.O.Box, 2003, Addis Ababa, Ethiopia
}

\begin{abstract}
This study was planned to identify the appropriate nitrogen fertilizer split application timing for food barley using 'HB-1307' food barley variety. This experiment was done at Holeta Agricultural Research center, West Shoa, Ethiopia. The split nitrogen application times were $1 / 2$ at planting $+1 / 2$ at mid tillering, $1 / 2$ at planting + $1 / 2$ at anthesis, nil at planting $+1 / 2$ at mid tillering $+1 / 2$ at anthesis, nil at planting + full at mid tillering, nil at planting + full at anthesis, $1 / 2$ at planting $+2 / 3$ at mid tillering, $1 / 3$ at planting $+1 / 3$ mid tillering $+1 / 3$ at anthesis, nil at planting $+1 / 3$ mid tillering $+2 / 3$ at anthesis, $2 / 3$ at planting $+1 / 3$ mid tillering, $2 / 3$ at planting $+1 / 3$ at anthesis, full at planting and negative control. The experiment was laid out randomized complete block design with three replications. Timing of split nitrogen fertilizer applications has significant effect on the yield and yield component of food barley. Application of nitrogen fertilizer one third at sowing plus two third at mid tillering gave the highest grain yield. This application method gave a yield advantage of $9.96 \%$ over the commonly practiced $1 / 2$ at sowing and $1 / 2$ at mid tillering. It also gave the highest economic return and agronomic Nitrogen Use Efficiency.
\end{abstract}

Keywords: split application timing ,nitrogen fertilizer, nitisols, food barley

DOI: $10.7176 /$ JNSR/12-9-02

Publication date:May $31^{\text {st }} 2021$

\section{INTRODUCTION}

Barley is one of the staple food crops in Ethiopia. Barley assumes fourth position in total cereal production in the world after wheat, rice, and maize. In Ethiopia, It ranks fourth after tef, maize, and sorghum in terms of cereal area production. It covers an area of about 951,993 ha, but its national average yield is still low at 2.1 ton ha-1 (CSA, 2018). Barley serves as a major animal fodder, base malt for beer and certain other distilled beverages.

The most important crop-yield limiting factor in the world is nitrogen, together with water (Mueller et al., 2012). Adoption of good $\mathrm{N}$ management strategies often result in large economic benefits to farmers. Among the plant nutrients, $\mathrm{N}$ plays a very important role in crop productivity (Amanullah et al., 2008a). $\mathrm{N}$ is frequently the most used and also the most costly mineral nutrient required for cereal production (Clark, 1990). Barley is very sensitive to insufficient $\mathrm{N}$ and very responsive to $\mathrm{N}$ fertilization. $\mathrm{N}$ is the key element in achieving consistently high yields in cereals. $\mathrm{N}$ is a constituent of many fundamental cell components such as nucleic acids, amino acids, enzymes, and photosynthetic pigments. Since $\mathrm{N}$ is a constituent of chlorophyll as well as the CO2 fixing enzyme Rubisco. $\mathrm{N}$ content is indirectly a determinant of the rate of photosynthesis, dry matter accumulation, and economic yield (Evans, 1983). The rate of uptake and partition of $\mathrm{N}$ is largely determined by supply and demand during various stages of plant growth. However, it has been estimated that $50 \%-70 \%$ of the $\mathrm{N}$ provided to the soil is lost due to volatilization, runoff, denitrification and leaching (Hodge et al., 2000).

For environmental and economic reasons, nitrogen fertilizers should be utilized as efficiently as possible in agriculture. The nitrogen use efficiency of plant depends on several factors including application time, application rate of nitrogen fertilizer, cultivar and climatic conditions (Okamoto and Okada, 2004). The management of the time of nitrogen application is essential to ensure sustained nutrition at the end of vegetative growth. Therefore, the total amount of $\mathrm{N}$ should be divided into suitable fractions to be applied to best satisfy the requirement of the growing barley crop. The aim is to avoid increasing early vegetative growth and to encourage the development of the upper most green parts to directly involved in grain formation. Too late application, may lead to $\mathrm{N}$ starvation whereas too early supply may also increase tillering and vegetative density. On completion of tillering phase and at the onset of stem elongation it is important to eliminate any possibility of nitrogen starvation by applying the fertilizer in such a way that it can make tiller vigour, enables a high proportion of tillers to produce ears and extensive development of uppermost green tissue, good ear fertility and sufficient filling of the grain.

Nitrogen application at proper dose has the most important effect in terms of increasing crop production. Proper dose of $\mathrm{N}$ increased leaf area, tillers formation, leaf area index and leaf area duration and this increase led to much greater production of dry matter and grain yield. In order to obtain greatest advantage from the fertilizer use the fertilizer should not only be applied in optimum quantity at recommended rate but also at right time as timely $\mathrm{N}$ application is one of the agronomic technique which has helped considerably in increasing the $\mathrm{N}$ use 
efficiency (NUE). Moll et al.,(1982) defined NUE as being the yield of grain per unit of available $\mathrm{N}$ in the soil. This comes down to developing appropriate recommendations that match crop nutrient requirements fertilizer additions and minimize nutrient losses from fields (Johnston and Bruulsema, 2014). It is now very well established that for most crops $\mathrm{N}$ must be applied in two or three split doses coinciding with the crop growth stages when its requirement is high therefore, it is high time to assess the effect of time of application of the recommended $\mathrm{N}$ fertilizer to increase the fertilizer use efficiency in food barley.

Split applications reduce the exposure of $\mathrm{N}$ in saturated soils where the potential for losses such as leaching and denitrification are increased. Increasing fertilizer use efficiency is very important, particularly in developing countries where the fertilizer is very expensive driven mainly by increases in the price of natural gas. Hence, splitting $\mathrm{N}$ fertilizer application in order to follow the $\mathrm{N}$ requirements by the crop throughout the growing season is probably the best strategy to achieve high grain yields. Economical and appropriate method of application needs to be determined to enhance productivity and profit of the growers under given situation (Manzoor et al., 2006). Appropriate timing of $\mathrm{N}$ application and rates are crucial for meeting crop needs and indicate considerable opportunities for improving NUE. Limited research has been done on the effects of time of application in relation to improving grain yield of food barely. Hence, this study was initiated to study the different $\mathrm{N}$ time of applications on the yield and yield components of food barley, economic feasibility and agronomic $\mathrm{N}$ use efficiency.

\section{MATERIALS AND METHODS}

The experiment was conducted for two years (2015 and 2016) during the main cropping season at Holeta Welmera wereda, West Shoa, on farmers field in the central highlands of Ethiopia. The environment is seasonally humid and the soil type was reddish brown Eutric Nitisol (IUSS Working Group WRB, 2006). Holeta is located between $09^{\circ} 03^{\prime} \mathrm{N}$ latitude and $38^{\circ} 30^{\prime} \mathrm{E}$ longitude, $30 \mathrm{~km}$ west of Addis Ababa, at an altitude of about $2400 \mathrm{~m}$ above sea level. The long- term average annual rainfall is $1100 \mathrm{~mm}$, about $85 \%$ of which is received from June to September with the remainder from January to May. The average minimum and maximum air temperatures are $6.2^{\circ} \mathrm{C}$ and $22.1^{\circ} \mathrm{C}$, respectively.

\section{Experimental set-up and procedure}

The experiment was laid out randomized complete block design with three replications. The timings of Nitrogen application were adjusted according to Zadoks decimal growth stage for barley (Zadoks et al., 1974) at the time when moisture is available for nutrient dissolution and absorption. Accordingly, treatments were comprised of eleven different times of $\mathrm{N}$ fertilizer application and a negative control: $\mathrm{T} 1=1 / 2$ at planting $+1 / 2$ at mid tillering, $\mathrm{T} 2=1 / 2$ at planting $+1 / 2$ at anthesis, $\mathrm{T} 3=$ nil at planting $+1 / 2$ mid tillering $+1 / 2$ at anthesis, $\mathrm{T} 4=$ nil at planting + full at mid tillering, T5 $=$ nil at planting + full at anthesis, T6 $=1 / 2$ at planting $+2 / 3$ at mid tillering, T7 $=1 / 3$ at planting $+1 / 3$ mid tillering $+1 / 3$ at anthesis, $\mathrm{T} 8=$ nil at planting $+1 / 3$ mid tillering $+2 / 3$ at anthesis, $\mathrm{T} 9=2 / 3$ at planting $+1 / 3$ mid tillering, T10 $=2 / 3$ at planting $+1 / 3$ at anthesis, T11 $=$ full at planting and $\mathrm{T} 12=$ negative control (without input)). The same rate of recommended $\mathrm{N}(60 \mathrm{~N} \mathrm{~kg}$ ha-1) was splitted and used for the experiment. Urea was used as the source of Nitrogen. Phosphorus at the rate of $69 \mathrm{~kg}$ ha-1 was applied to all plots at the time of sowing.

Sowing took place at the onset of rainfall, with a seeding rate of $125 \mathrm{~kg}$ ha-1 in early June. In each plot barley was sown at inter row spacing of $20 \mathrm{~cm}$ by drilling with a depth of at about $2-4 \mathrm{~cm}$. The recommended phosphorus fertilizer amount (69 kg P ha-1) was uniformly applied as triple super phosphate (TSP) to all plots at planting. $\mathrm{N}$ was applied after weeding in the presence of moisture to avoid the potential loss of $\mathrm{N}$ into the atmosphere. Other agronomic practices were applied based on research recommendations. The data were subjected to analysis of variance using the general linear model procedure of SAS statistical package version 9.3 (SAS Inc., 2013). Means of treatments were separated using the least significant difference (LSD) at 5\% level. To assess the costs and benefits associated with different treatments the partial budget technique as described by CIMMYT (1988) was applied on the yield results. Economic analysis was done using the prevailing market prices for inputs during the period of the experiment applied at planting, tillering, anthesis and also for outputs at the time the crop was harvested. The economic analysis also considered components of the labor cost for land preparation, planting, weeding and harvesting. All costs and benefits were calculated on hectare basis in Ethiopian Birr (Birr ha-1). Agronomic NUE was calculated as extra kilogram of grain per extra kilogram of $\mathrm{N}$ applied (Hatfield and Prueger, 2004).

\section{RESULT AND DISCUTION}

\section{Weather}

The total rainfall amount and precipitation pattern for 2016 was better compared with long-term average and 2015 (Figure 1). The rainfall amounts recorded for July and September were noticeably higher in 2016 than in 2015. When compared with a 30 year average, rainfall in July 2016 was elevated by $70 \mathrm{~mm}$ but lesser by 167 
$\mathrm{mm}$ in 2015. Rainfall in September 2016 and 2015 was lesser by 9 and $69 \mathrm{~mm}$, when compared with a 30 year average, respectively. Average moisture received in 2016 created conducive environment for food barley growth and development. On the contrary, since rainfall received in 2015 was much lower it was not suitable for growth and development of barley.

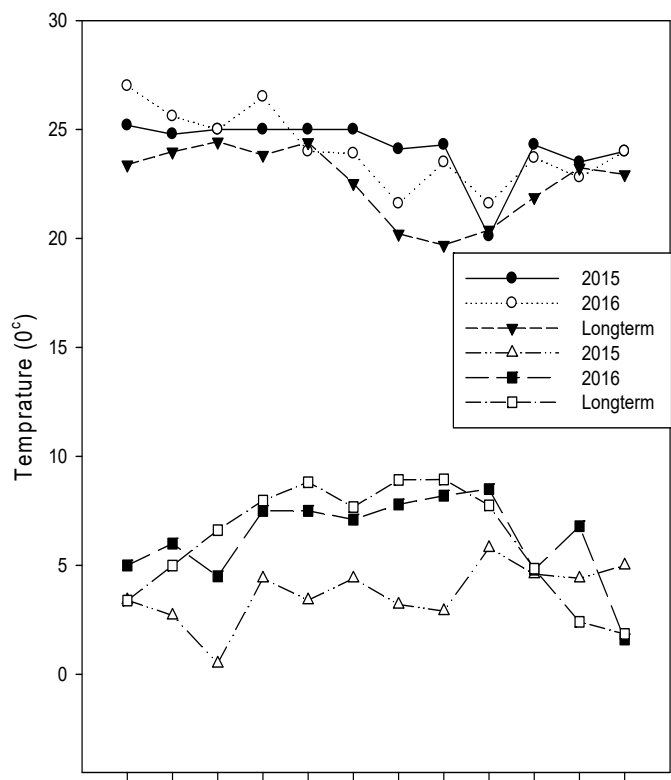

Jan Feb Mar Apr May June July Aug Sep Oct Nov Dec

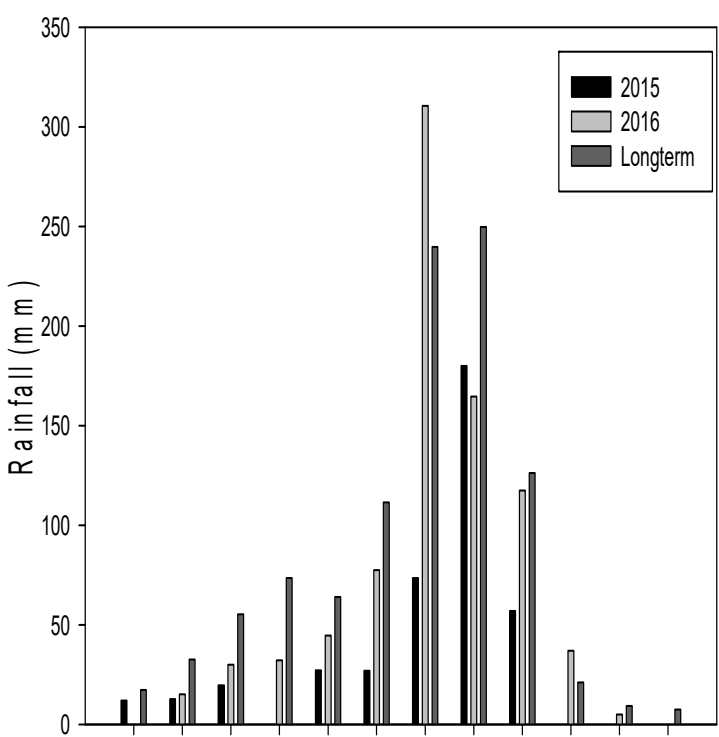

Jan Feb Mar Apr May June July Aug Sep Oct Nov Dec

Figure 1. Mean monthly maximum, minimum air temperatures and monthly total rainfall for 2015 and 2016 cropping seasons, and the 30-year average rainfall at Holeta Research Center.

\section{Physical and chemical properties of the experimental site}

Physical and chemical properties of soils critically affect the growth and the development of food barley. The analytical results indicated the textural class of the soil was predominantly clay with strong acidic property (Table 1).

Table 1: Physical and chemical soil characteristics of the experimental field

\begin{tabular}{ll}
\hline Parameter & Value \\
\hline Clay & 57.1 \\
Silt & 27.2 \\
Sand & 15.7 \\
pH $1: 2.5$ H2O & 5.21 \\
OC $(\%)$ & 1.87 \\
Total N & 0.20 \\
Available P (Bray II) & 5.50 \\
\hline
\end{tabular}

Yield and yield components of food barley

The responses of the grain yield, above ground biomass yield, spike length and harvest index to time of $\mathrm{N}$ split fertilization combined data are demonstrated in Table 2. There were significant $(\mathrm{P}<0.05)$ differences between years in the parameters of grain yield, above ground biomass yield and spike length. Grain yield, biomass yield and spike size was better in the second year (2016). This is due to to the better rain fall received in 2016 than 2015 as mentioned above. This conducive environment help for food barley growth and development. On the contrary, since rainfall received in 2015 was much lower it was not suitable for growth and development of barley.

Time of $\mathrm{N}$ application had a significant $(\mathrm{P}<0.01)$ effect on grain yield, biomass yield and spike length and harvest index. Significantly higher grain and biomass yield was obtained by $1 / 3$ at planting $+2 / 3$ at mid tillering though it did not show significant difference with $1 / 2$ at planting $+1 / 2$ mid tillering. This finding is in line with the findings of numerous authors (Tanner et al., 1992; Ramos, 1995; Gelato et al., 2008; Mohammad et al., 2011; ) who reported higher grain yields due to one third and two third split applications of $\mathrm{N}$ at sowing and mid tillering, respectively, relative to applications of nitrogen all at sowing and mid tillering crop stage, especially when rainfall is heavy and continuous during the growing season which is also true in central highlands of 
Ethiopia. This $\mathrm{N}$ application timing might have enhanced uptake of $\mathrm{N}$ during these stage and there by increased crop performance and ultimately grain yield. Most of the investigations on time of $\mathrm{N}$ fertilizer application are geared towards split-applications to synchronize timing of fertilization according to the crop demand and increase grain yield.

$\mathrm{N}$ split application time $1 / 3$ at planting $+2 / 3$ at mid tillering gave $9.96 \%$ a grain yield advantage over the recommended $\mathrm{N}$ application time (1/2 at planting $+1 / 2$ at mid tillering) which revealed that food barley require most of their $\mathrm{N}$ to be applied at mid tillering than at planting. Applying all the recommended $\mathrm{N}$ at planting brought about lesser yield than the split applications of $1 / 3 \mathrm{~N}$ at planting $+2 / 3$ at mid tillering which suggests that applying the entire $\mathrm{N}$ for food barley was not the most efficient. Grain yield increased with split application of $\mathrm{N}$ being maximum in treatment receiving larger quantity of $\mathrm{N}$ applied at mid tillering than at planting. Increased grain yields due to split $\mathrm{N}$ application at appropriate growth stage of food barley could be attributed to increased biomass production and improved harvest index with split $\mathrm{N}$ fertilization at appropriate growth stage of barley. The higher grain yield under this treatment is as the result of growth and development through efficient assimilation and utilization of available nitrogen by the growing plants during the entire growth period. The lowest yield were recorded under the T12 treatment, where nitrogen was not applied and followed by application of $\mathrm{N}$ full at the time of anthesis which was possibly due to reduced translocation of carbohydrates from source leaves and stem to sink.

Significantly higher above ground biomass yield was obtained by $1 / 3$ at planting $+2 / 3$ at mid tillering though it did not show significant difference with application of $\mathrm{N} 2 / 3$ at planting $+1 / 3$ mid tillering and full at planting. Significantly higher spike length was obtained by $1 / 3$ at planting $+2 / 3$ at mid tillering though it did not show significant difference with application of $1 / 2$ at planting $+1 / 2$ mid tillering which might resulted in higher grain yield of this treatment. Shortest length of spike was observed in T12 treatment where nitrogen was not applied.

Analysis of variance also revealed that effect of time of split $\mathrm{N}$ applications on harvest index (The ratio of the economic yield to the biological yield) was highly significant $(\mathrm{P}<0.001)$ (Table 2$)$. Significantly greater harvest index was obtained with the application of $1 / 3$ at sowing $+2 / 3$ at mid tillering though there was no significant statistical difference with split time of $\mathrm{N}$ applications of $1 / 2$ at planting $+1 / 2$ mid tillering, $1 / 2$ at planting $+1 / 2$ at flower initiation, nil at planting, $1 / 2$ at mid tillering $+1 / 2$ at anthesis, nil at planting + full at mid tillering, Nil at planting $+1 / 3$ at mid tillering $+2 / 3$ at anthesis and $2 / 3$ at planting $+1 / 3$ at anthesis as shown in Table 2.

Table 2: Effect of time of $\mathrm{N}$ fertilizer application on yield and yield components of food barley

\begin{tabular}{|c|c|c|c|c|}
\hline Factor & Grain & Biomass & Spike & Harvest \\
\hline Year & $\begin{array}{l}\text { Yield } \\
\left(\mathrm{kg} \mathrm{ha}^{-1}\right)\end{array}$ & $\begin{array}{l}\text { yield } \\
\left(\mathrm{kg} \mathrm{ha}^{-1}\right)\end{array}$ & $\begin{array}{l}\text { length } \\
(\mathrm{cm})\end{array}$ & $\begin{array}{l}\text { index } \\
(\%)\end{array}$ \\
\hline 2015 & $2761 b$ & $7365 b$ & $5.8 \mathrm{~b}$ & 37.3 \\
\hline 2016 & $2907 \mathrm{a}$ & $8239 a$ & $6.2 \mathrm{a}$ & 35.5 \\
\hline $\mathrm{LSD}_{0.05}$ & 196.2 & 470.6 & 0.18 & ns \\
\hline Time of $\mathrm{N}$ application & & & & \\
\hline $\mathrm{T} 1=1 / 2$ at planting $+1 / 2$ mid tillering & $3623 \mathrm{ab}$ & $8946 \mathrm{a}$ & $6.5 \mathrm{ab}$ & $40.5 \mathrm{ab}$ \\
\hline $\mathrm{T} 2=1 / 2$ at planting $+1 / 2$ at flower initiation & $2723 \mathrm{dc}$ & $7208 \mathrm{~cd}$ & $5.9 \mathrm{~cd}$ & 39.6abc \\
\hline $\mathrm{T} 3=$ nil at planting $1 / 2$ at mid tillering $+1 / 2$ at anthesis & $2681 d$ & $7625 \mathrm{bc}$ & $5.9 \mathrm{~cd}$ & $37.5 \mathrm{abc}$ \\
\hline $\mathrm{T} 4=$ nil at planting + full at mid tillering & $2967 \mathrm{dc}$ & $8193 \mathrm{abc}$ & $5.9 \mathrm{~cd}$ & $36.8 \mathrm{abc}$ \\
\hline $\mathrm{T} 5=$ Nil at planting + full at anthesis & $2001 \mathrm{e}$ & $6402 d$ & $5.7 \mathrm{~d}$ & $31.9 \mathrm{dc}$ \\
\hline $\mathrm{T} 6=1 / 3$ at planting $+2 / 3$ at mid tillering & $3984 a$ & $9228 \mathrm{a}$ & $6.8 \mathrm{a}$ & $43.5 \mathrm{a}$ \\
\hline $\begin{array}{l}\mathrm{T} 7=1 / 3 \text { at planting }+1 / 3 \text { at mid tillering }+1 / 3 \text { at } \\
\text { anthesis }\end{array}$ & $3189 \mathrm{bc}$ & $8657 \mathrm{ab}$ & $6.2 \mathrm{bc}$ & $36.9 \mathrm{abc}$ \\
\hline $\begin{array}{l}\mathrm{T} 8=\mathrm{Nil} \text { at planting }+1 / 3 \text { at mid tillering }+2 / 3 \text { at } \\
\text { anthesis }\end{array}$ & $2998 \mathrm{~cd}$ & $7630 \mathrm{bc}$ & $6.2 \mathrm{bc}$ & $40.0 \mathrm{ab}$ \\
\hline $\mathrm{T} 9=2 / 3$ at planting $+1 / 3$ at mid tillering & $3002 \mathrm{~cd}$ & $8875 \mathrm{a}$ & $6 \mathrm{~cd}$ & $34.4 b c$ \\
\hline $\mathrm{T} 10=2 / 3$ at planting $+1 / 3$ at anthesis & $2696 d$ & $7361 \mathrm{~cd}$ & $6 \mathrm{~cd}$ & $36.7 \mathrm{abc}$ \\
\hline $\mathrm{T} 11=$ full at planting & $3034 d c$ & $8972 \mathrm{a}$ & $6.2 \mathrm{~cd}$ & $34.2 \mathrm{bc}$ \\
\hline T12=Negative Control (No input) & $1113 f$ & $4528 \mathrm{e}$ & $4.5 \mathrm{e}$ & $25.0 \mathrm{~d}$ \\
\hline $\mathrm{LSD}_{0.05}$ & 480 & 1153 & 0.43 & 8.0 \\
\hline Significance level & $* * *$ & $* * *$ & $* * *$ & $* *$ \\
\hline $\mathrm{CV}(\%)$ & 14.6 & 12.7 & 6.2 & 18.7 \\
\hline
\end{tabular}

$* *, * * *$ Significant at $\mathrm{P}<0.01$ and $\mathrm{P}<0.001 ; \mathrm{ns}=$ not significant 
Economic advantage was also obtained by time of $\mathrm{N}$ split-applications. The economic analysis showed that split $\mathrm{N}$ fertilizer application $1 / 3$ at sowing $+2 / 3$ at mid tillering was the appropriate time of $\mathrm{N}$ application due to the fact that it gave the highest net economic benefit (Table 2). Time of $\mathrm{N}$ split application of $1 / 3$ at sowing $+2 / 3$ at mid tillering gave a $10 \%$ and $29 \%$ monitory advantage in Ethiopian Birr over the recommended $\mathrm{N}$ application of $1 / 2$ at sowing $+1 / 2$ at mid tillering and $1 / 3$ at sowing $+1 / 3$ at mid tillering $+1 / 3$ at anthesis, respectively. Application of $1 / 3 \mathrm{~N}$ at sowing $+2 / 3$ at mid tillering was more economically beneficial than other-splitapplications. N Use Efficiency (NUE) expressed as grain production per unit of $\mathrm{N}$ applied, indicated that food barley had the highest NUE when the $\mathrm{N}$ was applied in split of $1 / 3$ at sowing $+2 / 3$ at mid tillering (Table 3 ).

Table 2: Economic analysis for split application of $\mathrm{N}$ fertilizer on food barley

\begin{tabular}{llllll}
\hline No. & Treatments & $\begin{array}{l}\text { Grain } \\
\text { Yield } \\
\text { (kg ha- } 1)\end{array}$ & $\begin{array}{l}\text { Total } \\
\text { variable } \\
\text { cost }\end{array}$ & $\begin{array}{l}\text { Gross } \\
\text { profit }\end{array}$ & $\begin{array}{l}\text { Net } \\
\text { benefit }\end{array}$ \\
\hline T1 & $1 / 2$ at sowing $+1 / 2$ mid tillering & 3623 & 4000 & 28984 & 24984 \\
T2 & $1 / 2$ at sowing $+1 / 2$ at flower initiation & 2723 & 4000 & 21784 & 17784 \\
T3 & nil at sowing, $1 / 2$ at mid tillering $+1 / 2$ at anthesis & 2681 & 3700 & 21448 & 17748 \\
T4 & nil at sowing + full at mid tillering & 2967 & 3700 & 23736 & 20036 \\
T5 & Nil at sowing + full at anthesis & 2001 & 3700 & 16008 & 12308 \\
T6 & $1 / 3$ at sowing $+2 / 3$ at mid tillering & 3984 & 4300 & 31872 & 27572 \\
T7 & $1 / 3$ at sowing $+1 / 3$ at mid tillering $+1 / 3$ at anthesis & 3189 & 4300 & 25512 & 21212 \\
T8 & Nil at sowing $+1 / 3$ at mid tillering $+2 / 3$ at anthesis & 2998 & 4000 & 23984 & 19984 \\
T9 & 2/3 at sowing $+1 / 3$ at mid tillering & 3002 & 4000 & 24016 & 20016 \\
T10 & 2/3 at sowing $+1 / 3$ at anthesis & 2696 & 4000 & 21568 & 17568 \\
T11 & full at sowing & 3034 & 4000 & 24272 & 20272 \\
\hline
\end{tabular}

Table 3: Agronomic N Use Efficiency food barley as affected by split N fertilizer applications

\begin{tabular}{llc}
\hline No. & Treatments & Agronomic N Use Efficiency \\
\hline T1 & $1 / 2$ at sowing $+1 / 2$ mid tillering & 36.4 \\
T2 & $1 / 2$ at sowing $+1 / 2$ at flower initiation & 23.3 \\
T3 & nil at sowing, $1 / 2$ at mid tillering $+1 / 2$ at anthesis & 22.7 \\
T4 & nil at sowing + full at mid tillering & 26.9 \\
T5 & Nil at sowing + full at anthesis & 12.9 \\
T6 & $1 / 3$ at sowing $+2 / 3$ at mid tillering & 41.6 \\
T7 & $1 / 3$ at sowing $+1 / 3$ at mid tillering $+1 / 3$ at anthesis & 30.1 \\
T8 & Nil at sowing $+1 / 3$ at mid tillering $+2 / 3$ at anthesis & 27.3 \\
T9 & $2 / 3$ at sowing $+1 / 3$ at mid tillering & 27.4 \\
T10 & $2 / 3$ at sowing $+1 / 3$ at anthesis & 22.9 \\
T11 & full at sowing & 27.8 \\
\hline
\end{tabular}

\section{CONCLUSION}

Food barley growth yield and yield components were significantly affected by time split $\mathrm{N}$ fertilizer application. From the present study it is evident that time of split $\mathrm{N}$ applications generally improved grain yield of food barley. Time of split $\mathrm{N}$ fertilizer application $1 / 3$ at sowing and mid tillering stage brought about the higher of spike length, grain yield, and aboveground biomass yield and harvest index when compared with other split $\mathrm{N}$ time applications. Application of $\mathrm{N}$ fertilizer $1 / 3$ at sowing plus $2 / 3$ at mid tillering gave the highest grain yield of food barley. In general time of nitrogen fertilizer application at different plant growth stages need a great attention on the existing moisture in the soil at that time of application. So this split nitrogen application time also require the existence of moisture in the soil for better use of the nitrogen fertilizer applied. Further investigations should be done to know the climatic effect on time of split nitrogen application of food barley..

\section{ACKNOWLDGEMENT}

The authors are grateful to Girma Desalegn, Solomon Sahlemariam, Berhanu Bogale and Beshadu Bedada. Great thanks also go to barley Improvement Research Team for their technical assistance. Holeta Agricultural Research Center is also acknowledged for all the logistics and managerial support provided during the experimental period.

\section{REFERENCES}

CIMMYT. 1988. From Agronomic Data to Farmer Recommendations: An Economics Training Manual. 
Completely revised edition. Mexico.

Clark, R.B. 1990. Physiology of cereals for mineral nutrient uptake, use and efficiency. In Crops as Enhancers of Nutrient Use, V.C. Baligar, and R.R. Duncan (eds.). San Diego: Academic Press. p 131-209.

(CSA) Central Statistical Agency. 2018. Report on area and production of major crops (private peasant holdings, Meher season) for 2017/2018. Statistical Bulletin 586. Addis Ababa, Ethiopia.

Evans, J. R. 1983. Nitrogen and photosynthesis in the flag leaf of wheat (Triticum aestivum L.). Plant Physiol. 72 : 297302.

Geleto, T., F. Tadesse, K. Nero, G. Gezu, H. Seboka, A. Bogale, \& Woyema, A. (2008). Recommendations of production management practices. pp. 39-46. In: Kedir, N., Tilahun Gelato, G. and Allo Aman. (eds.). Fifteen years achievements. Oromia Agricultural Research Institute, Sinana Agricultural Research Center,Bale Robe, Ethiopia.

Hatfield, J.L., Prueger, J.H., 2004. Nitrogen Over-use, Under-use, and Efficiency. "New directions for a diverse planet". Proceedings of the 4th International Crop Science Congress, 26 Sep. - 1 Oct. 2004, Brisbane, Australia. Pp. 21-29.

Hodge, A., Robinson, D., Fitter, A. 2000. Are microorganisms more effective than plants at competing for nitrogen? Trends Plant Science 5, 304-308.

IUSS Working Group WRB. 2006. World reference base for soil resources A framework for international classification, correlation and communication (World Soil Resources Reports No. 103). Rome, FAO.

Johnston, A.M. \& Bruuslema, T.W. (2014). 4R nutrient stewardship for improved nutrient use efficiency. Precedia Engineering, 83, 365-370.

Manzoor, Z., R.I. Ali, T.H., Awan, N., Khalid and Ahmad, M. 2006. Appropriate time of nitrogen application to fine rice, Oryza sativa. Journal of Agricultural Resources, 44(4).

Mohammad, T.J., Mohammad, K.J. Ahmad, K., Mohammad, A., Farha, T., \& Dawood, J. (2011). Improving wheat productivity through source and timing of nitrogen fertilization. Pakistan Journal of Botany, 43(2),905-914.

Moll, R.H., Kamprath, J., \& Jackson, W.A. (1982). Analysis and interpretation of factors which contribute to efficiency of nitrogen utilization. Agronomy Journal, 74, 562-564.

Mueller, N.D., Gerber, J.S., Johnston, M., Ray, D.K., Ramankutty, N., Foley, J.A. 2012. Closing yield gaps through nutrient and water management. Nature 490, 254-257.

Okamoto, M. and Okada K. 2004. Differential responses of growth and nitrogen uptake to organic of nitrogen four gramineous crops. Journal. Exp. Bot. 55 (402): 1577 - 1585.

Ramos, J.m., Dela, I., \& Garcia, L.F. (1995). Barley response to nitrogen rate and timing in Mediterranean environment. Journal of agricultural science, 125, 175-182.

SAS Institute. 2013. SAS User's Guide, Version 9.3; SAS Institute: Cary, NC, USA.

Tanner, D.G. \& Mwangi, W.M. (1992). Current issues in wheat research and production in Eastern, Central and Southern Africa: Constraints and achievements. pp. 17-36. In: Tanner, D.G., and Mwangi, W.M. (eds.). The Seventh Regional Wheat Workshop for Eastern, Central and Southern Africa. Nakuru, Kenya, CIMMYT. 